\title{
ПСИХОИСТОРИЧЕСКИЙ ДИСКУРС УКРАИНСКОЙ ИСТОРИИ ХХ-ХХІ СТ.СТ.
}

\begin{abstract}
В статье авторами рассматриваются некоторые периоды украинской истории через призму психоистории. Особенно это касается бурного ХХст., когда именно проблемы тоталитаризма заметно волновали исследователей. За основу исследования данной проблемы берётся культовое для психоисторика исследование Л.Демоза и, как пример целостной модели, литературоведческая психоисторическая модель Н.Зборовской.

По Л.Демозу абсолютно линейной есть связь особенностей воспитания и детства лидеров и стилем их психополитики. В своей работе он так же ставит вопрос «победит ли демократия?», исследователь проводит аналогии между процессом перестройки и думскими экспериментами 1905-1907 г.г.

В культурном пространстве XX в., который препарировала Н.Зборовская, исследовательница выделила постмодерн как ключевое культурное явление, рассматриваемое с психоаналитической точки зрения.

Украина вошла в XXI век целым рядом острейших кризисов и революций, которые поставили под угрозу все перспективы её жизнедеятельности. Осознание этой необходимости психического обновления общества реализуется нашим государством через привлечение социальных психологов к различным, прежде всего учебным, заведениям. Овладение теми стратегий, которые повышают личностную эффективность каждого человека, укрепляют его психическое здоровье, является признаком XXI века. Следующим конструктивным примером подобной стратегии авторы считают коучинг. Коучинг является действенной составляющей концепции управления человеческими ресурсами, поскольку применяется в планировании, отборе, адаптации, мотивации, обучении, развитии, аттестации и оценке персонала. Это система, которая позволяет увидеть, почувствовать новые подходы и возможности, позволяет раскрыть потенциал и «навести порядок» во многих сферах общественной жизни. Она стимулирует индивида к повышению личной эффективности не через истощение психоэмоциональной сферы, а через совокупность специальных инструментов , направленных в сферу самораскрытия.
\end{abstract}

Ключевые слова: Психоисторический дискурс, Л.Демоза,Украина.

Рассматривая предыдущие периоды украинской истории через призму психоистории, нам не однократно приходилось повествовать о сложности подобного исследования из-за недостачи историографического обеспечения этой проблемы. Особенно это заметно при рассмотрении бурного ХХст., хотя именно

\footnotetext{
${ }^{1}$ Anna Chechelnitskaya PhD, University of Customs and Finance, Dnepropetrovsk, corresponding author,: e-mail: angelochek05@list.ru

${ }^{2}$ Anna Samokina, Assistant Economist on accounting and business analysis of " Azbo " ltd
} 
проблемы тоталитаризма заметно волновали исследователей. Что мы можем сейчас взять за основу? С нашей точки зрения, это культовое для психоисторика исследование Л.Демоза ${ }^{3}$ и , как пример целостной модели, литературоведческая психоисторическая модель Н.Зборовской ${ }^{4}$.

Обращение к первому источнику сразу провоцирует активизацию критической позиции из-за конфликта восприятия нашей, украинской, реальности исследователем иностранным и исследователем, грубо говоря, местным. Тексты Л.Демоза рождают терминологические вопросы, которые следует обозначить: в первую очередь отсутствует территориальное и политическое определение Украины как таковой.

Раздел, который психоисторически характеризует XX ст., имеет название «Бархатная революция: детские корни демократических движений в Советском Союзе и Восточной Европе», но во вступительной части говорится об особенностях жестокого воспитания детей вРоссииXVIII ст. Учитывая территориальноисторическое разделение украинских земель в данный период, особенности региональной и казацкой педагогики, мы возьмём в работу лишь ссылку Л.Демоза на общий принцип педагогики того времени, очерченный украинским историком Н.Костомаровым. Последний утверждал, что в отношениях отцов и детей господствовал дух рабства 5 .

Буреломные события революции 1917-1920 -х г.г. принесли новые принципы воспитания, которые отменили некоторые традиционные формы: психологическое насилие со стороны родителей было минимизировано созданием детских садов и яслей, но прогрес был замедленным до 1930-х г.г., «когда жизнь советских детей становится всёболее похожей на детство в других современных странах» ${ }^{6}$. Качественным маркером состояния общества является наличие и распространение женского, а особенно высшего женского, образования.

Многомерность истории снова возвращает нас к проблеме политического лидерства, а особенно, к нюансам сценариев детства знакових фигур XX века В.Ленина, И.Сталина, М.Горбачёва.

По Л.Демозу, абсолютно линейной есть связь особенностей воспитания и детства обозначенных лидеров и стилем их психополитики.

Мать Ленина воспитывалась и воспитывала на спартанский манер, с обязательным участием кормилицы. Л.Демоз ссылается на тех авторов, которые уведомляют, что В.Ленин не умел ходить до трёх лет и считался неуравновешенным ребёнком, который вырос вэмоционально холодного, безжалостного человека с проблемами потенции. Понятия демократичности для него просто не существовало ${ }^{7}$.

Избиения, которым подвергал И.Сталина отец, с попытками убийства, привели к тому, что тот бил собственных детей, а его лидерская доктрина была ориентирована на уничтожение.

\footnotetext{
3 Л. Демоз, Психоистория, Ллойд Демоз, Ростов-на-Дону, 2000.

${ }^{4}$ Н. Зборовська, Код украӥнської літератури : проект психоісторіӥновітньої української літератури, Н. Зборовська, К. Академвидав, 2006.

5 Л. Демоз, Психоистория, Ллойд Демоз, Ростов-на-Дону, 2000, с. 442.

${ }^{6}$ Ibidem

${ }^{7}$ Ibidem, c. 443.
} 
М.Горбачёв, первый и последний президент СССР, инициатор перестройки, имел, по свидетельству ${ }^{8}$, счастливое детство, склонность к уравновешенности и способность испытывать романтическое тяготение к женщине. Поэтому ему была присуща ориентация на демократичность, неприятие политического пеленания и открытого насилия.

C нашей точки зрения в подобных характеристиках присутствует односторонность, не многомерность, поскольку автоматически возникают вопросы психодиагностического плана, как, например, повлияло на Ленина наличие братьев и сестёр, смерть и казнь некоторых из них, поскольку символические братья и сёстры всегда окружают политических лидеров впоследствии. Соответственно, как повлияла на Сталина ранняя смерть детей в родительской семье? Почему потерпели крах реформы Горбачёва при наличии такого позитивного личного психосценария?

Возможно, что упреждая подобные детализации, Л.Демоз делает обобщающий, психоисторически взвешенный вывод: «... конец коммунизма был вызван не экономическим упадком (на самом деле, в предшествующее ему десятилетие наблюдался экономический прогресс) и не миллиардными затратами Америки на повышение мощности своего вооружения (как утверждал Рональд Рейган), и не в том дело, что коммунизм «одряхлел и умер», по выражению одного писателя.

Мирные революции, в отличие от насильственных, являются результатом того, что в своё время родители стали больше любить детей. Это не революции ненависти, а революции любви. Эти революции производятся не экономическими классами, а психоклассами, новыми типами исторической личности»9.

На примере демозовских прогнозов, которые для нас уже есть историческим прошлым, можно проверить их точность.

Поставив вопрос «победит ли демократия?», исследователь проводит аналогии между процессом перестройки и думскими экспериментами 1906 года. И считает, что успех не может быть гарантирован, поскольку плохое отношение к детям существует во многих союзных республиках. Но это не одинокие примеры в европейской педагогике. Например, в Германии в 1964 году, согласно официальной статистике, половина детей знала, что такое избиение палкой, не говоря уже о сексуальных домогательствах.

Показательным маркером отношения к детству является уровень детской смертности, которую автор линейно объединяет с уровнем потенциальной демократичности. Цитируем: «Из девяти стран, недавно переживших политическую революцию, у пяти отмечается низкое число умерших детей на тысячу, а стало быть, они имеют наибольшие шансы провести демократическую реформу мирным путём: ГДР $(9,6)$, Чехословакия $(15,3)$, Болгария $(15,4)$, Венгрия (17) и Польша $(18,5)$. Две страны со средним коэффициентом детской смертности тоже идут к демократической реформе, но там этот процесс в большей степени сопряжён с насилием. Это Румыния $(23,4)$ и СССР $(26,0)$. И, наконец, в двух странах с наиболее высокими коэффициентами детской смертности успех демократии невозможен. Это Югославия $(28,8)$ и Албания $(44,8)^{10}$.

Ликвидация так называемого «социалистического лагеря» на рубеже 1980-1990 -

\footnotetext{
${ }^{8}$ Ibidem.

${ }^{9}$ Ibidem, c. $443-444$.

${ }^{10}$ Ibidem, c. 445.
} 
х г.г. показала точность данного прогноза. Но события последующих десятилетий европейской истории прикасаются к следующему слою прогнозов Л.Демоза. Речь идёт о 2000-х г.г., как об эре европейского мира. На то время процесс оформления ЕС свидетельствует в пользу реализации прогнозов. События же последнего времени, особенно касательно Украины, показывают переформатирование всего европейского пространства и указывают на необходимость новых прогнозов.

Вкультурном пространстве XX в., которое препарировала Н.Зборовская, исследовательница выделила постмодерн как ключевое культурное явление, рассматриваемоес психоаналитической точки зрения.

Эпоху постмодернизма она характеризует как регрессивный шаг после современного индивидуализма, когда возникает эра пустоты, и отдельная личность превращаетсяв ничто: «Украинская Эра пустоты началась в 20-е годы XX в. потерямипринципа реальности, национальной романтики, одержимости кастрационным комплексом, сопровождавшиеся бессознательным поглощением угрожающего национального мира инородным мировоззрением, производством писателя-маргинала иокончательной потерей аристократического проекта литературы, направленного на идею государства ${ }^{11}$.

По мнению исследовательницы в 1930-50 г.г. распространенным становится тип писателя-имитатора, антитворца, который аккумулирует идею национальной бессознательности, нарушив архитипичную идею целостности(родительскоматеринский код, Бог).

Общеизвестным является признание соцреализма как базового культурного стиля советской эпохи, ключевым положением которого является имитация, тобишь имитация удовольствие от жизни, работы,имитация родителя в виде образа ЛенинаСталина, что, кстати, свидетельствует о деградации украинского мужества в истории. Заимствование христианской идеи воплощения Бога становится основой культа личности Сталина.

Употребление исследовательницей парных противопоставлений показывает нам процесс роста соцреалистического дискурса, например, милитаристский эпос О. Гончара «Знаменосцы» оппонирует аристократическому тексту А. Довженко «Украина в огне».

ОпределивГ.Тютюнника, Д. Павлычко, И. Драча как ключевых фигур шестидесятничества, Н.Зборовская характеризует последнее явление как наивный моральный мазохизм, который,увы, не имел мощной трансформации в сторону мужественного родительского характера. Исключением определяется творчество В. Стуса, а общая характеристика шестидесятников такова: «Благодаря различным проявлениям национального мазохизмашестидесятничество является диагностическим центром для психоанализа украинскойпостмодерности, когда усилению имперских механизмов расщепления способствовало неосознанное расщепление родительского и материнского кода в психологии национального творческого субъекта » ${ }^{12}$.

Н.Зборовская толкует постмодернизм как имперскую стратегию, направленную на опустошение национальных моделей мира, вдохновление империализма.

\footnotetext{
${ }^{11}$ N. Зборовська, Код украӥнської літератури : проект психоісторіїновітньої украӥнської літератури, Н. Зборовська, К. Академвидав, 2006, с. 321.

12 Ibidem, c. 352-353.
} 
Согласно этому просоветский украинский писатель-шут, поддаваясь на такую провокацию, становится объектом антинациональных имперских манипуляций, теряя независимую сущность. В контексте подобного видения отчаянной выглядит попытка П. Загребельного в лице Роксоланы возродить архетипную украинскую женственность с мощным родительским кодом мужества и не менее сильным материнским кодом витальности, целостность которой позволяет осуществлять разумную деконструкцию имперского мира. Антиподомявляется образ украинской женщины, созданный В. Шевчуком, направленный в тень ненасытной эрогенности.

1980-е гг характеризуются такими маргинальными субъектами украинского постмодерна как «сыновий» и «дочерний» психотипы. Ведущими стают донжуановский психотип и психотип проститутки, которые «продуцируют театрализованную богемную психопоетику и соответствующую ей психосемантику сминания национального характера до инфантильных позиций, фиксацию садоавангардистских интенций, состояния дезинтеграции, активизацию различных деструктивних импульсов(импульсов ненависти, стремления к убийству, некрофилии и т.п.) »13.

Как разворачиваются символические сюжеты украинского постколониализма через оппозицию «Дон Жуана» и «Командора», «Анны» и «Долорес» (согласно дефиниций Леси Украинки)? Типично украинский романтический и аморальный "Дон Жуан", следующий к тому, чтобы стать маскулинным«Коммандором», то есть реализовать психологическую модель возвращения имперского тоталитаризма или национального фашизма.Женский тип, т.н. сексуально властная «Анна», выдающая себя за преданную духовности «Долорес». На основе женского сюжета происходит демонический триумф имитационного психотипа феминистки (по аналогиис Марко Вовчок) над национальнотворящим психотипом (по аналоги с Лесей Украинкой).За всем этим стоит страх самопознания, интегрированный в нарциссизм.

Среди постмодерна восьмидесятников для Н.Зборовской заметной фигурой является О. Забужко, «в которой ярко выражена психология расщепленного творческого субъекта, рожденного в лоне украинского колониального мира на основе неосознанного конфликта в материнско- отеческом коде. Национально неопределенная женщина активизирует психотип проститутки, продуцирующей феминистический кастрационный дискурс, бессознательно направленный против украинского мужества » ${ }^{14}$.

Как же преодолеть комплексы и акцентуации украинского литературного пространства, которые исследовательница определяет как состояния дезинтеграции маргинального характера на основе онтогенетического отвращения к отцуматери,являющееся характерным для переходной эпохи. «Но переход от колониализма к независимой государственной структуре ставит важное онтологично-психологическое задание: преодолеть доведеные до максимума шизоидные состояния бессознательного национального характера, интегрировать национальное мужество и национальную женственность, выйти на путь интенсивного поиска украинского мировоззрения, который был бы ответственным за судьбу европейской цивилизации. Иначе - украинский характер ожидает

\footnotetext{
${ }^{13}$ Ibidem, c. 384.

${ }^{14}$ Ibidem, c. $467-468$.
} 
колониальное блуждание на основе неосознанного романтичного комплекса, ведущегок символической самокастрации ».

Если говорить о антропогенезе, психогенезе, которые реализуются в историческом процессе, то мы должны поставить чисто конкретный вопрос: если мы развили психоисторический дискурс в настоящее, то главным выводом должна быть наша деятельность. То есть речь идет, что мы как граждане, овладев определенным психоисторическим опытом, должны действовать«здесь и сейчас». Украина вошла в XXI век целым рядом острейших кризисов и революций, которые поставили под угрозу все перспективы её жизнедеятельности. Это рождает недопустимую степень социального напряжения, стремящегося к коллапсу. Осознание этой необходимости психического обновления общества реализуется нашим государством через привлечение социальных психологов к различным, прежде всего учебным, заведениям. Можно много упрекать за несовершенство работы этих специалистов, но они действуют. Овладение тех стратегий, которые повышают личностную эффективность каждого человека, укрепляют его психическое здоровье, является признаком XXI века.Следующим конструктивным примером подобной стратегии мы считаем коучинг. Пока мы говорим о нём на уровне общей эрудиции, постепенно вводя его в систему гуманітарного знания.

Коучинг (англ. Coaching) - метод консалтинга и тренинга, в процессе которого человек, называющийся «коуч», помогает обучающемуся достичь некой жизненной или профессиональной цели. В отличие от менторства, коучинг сфокусирован на достижении чётко определённых целей вместо общего развития ${ }^{15}$.

В общем смысле, коучинг - это процесс, в ходе которого отдельным людям и целым коллективам помогают действовать продуктивно и максимально реализовывать свои способности. Он включает раскрытие и использование сильных сторон людей, поддержку их в преодолении личных барьеров и ограничений в достижении лучших результатов, а также повышении результативности их работы в команде. Таким образом, эффективный коучинг требует акцента как на задаче, так и на отношениях между людьми.

Лайф-коучи помогают людям открывать для себя то, чего они хотят достичь в жизни, а также находить в себе силы для этого. Лайф коучинг помогает людям находить собственные ответы, а не искать решения вне себя

Профессиональный коучинг - это непрерывные профессиональные отношения, которые помогают людям создавать выдающиеся результаты в своей: личной жизни, карьере, бизнесе или организации. Посредством процесса коучинга клиенты углубляют свои знания, улучшают свой КПД (коэффициент полезного действия) и повышают качество своей жизни ${ }^{16}$.

Кто заказывает коучинг?

Коучинг заказывают предприниматели, собственники бизнеса, директора компаний, специалисты и профессионалы, а также люди, желающие перемен в своей жизни. Всех этих людей, несмотря на различия в сферах деятельности, опыта и компетенции, объединяет стремление к постоянному совершенствованию,

\footnotetext{
15Электронный ресурс, режим доступа:

http://www.rusnauka.com/21_NNP_2010/Pedagogica/70725.doc.htm

16 Режим доступу: http://nbuv.gov.ua/UJRN/vdumov_2013_21_7(3)_29
} 
повышению эффективности, желание добиваться большего и быстрее. Все они успешные люди и выбирают быть и оставаться успешными.

Когда заказывают коучинг?

1. Наступили или ожидаются серьёзные перемены в жизни.

2. Необходимо принимать важные, серьёзные решения.

3. Важно выработать новые профессиональные качества и приобрести или усовершенствовать навыки.

4. Необходимо выработать стратегию и создать конкретный план достижения целей.

5. Необходимо сделать жизнь более сбалансированной и целостной.

6. Необходимо открыть «второе дыхание», «вернуть себе силы» или найти источник вдохновения.

7. Важно осуществить прорыв к новому качеству жизни.

Почему заказывают коучинг?

Люди заказывают коучинг в различные периоды своей жизни. Особенно эффективным коучинг оказывается, когда:

1. Коучинг помогает держать фокус внимания на том, что по-настоящему важно клиенту, и обеспечивает клиента обратной связью, благодаря чему происходит развитие и совершенствование.

2. Коуч сохранит полную конфиденциальность, и с ним можно обговорить и решить всё то, что не оговоришь больше ни с кем (все -значит любые области жизни и жизнь в целом). Коуч ориентирован только на клиента и его цели.

3. Коуч - это производная от хорошего друга, превосходного тренера и профессионального консультанта, благодаря чему вы получаете одновременно больше, чем поддержку трёх в одном лице.

4. Коуч - это агент перемен, специалист и профессионал в создании изменений, благодаря чему, изменения, желаемые клиентом, осуществляются в самой лучшей для клиента форме.

5. Коучинг - это наиболее продуктивная форма внешней поддержки и лучшего пока просто не придумали.

Зачем заказывают коучинг?

Коучинг заказывают для того чтобы:

1. Добиваться более высоких результатов в жизни и карьере.

2. Повысить КПД: использовать своё время, улучшить качество результатов и повысить эффективность деятельности.

3. Выработать новые навыки и привычки: профессиональные, межличностные и личностные.

4. Перестать играть в игры «избегание», «оправдание», «откладывание» и прочее и начать играть в «активное достижение», «осознанный и ответственный выбор», «автор и создатель своей жизни» и так далее.

5. Определить систему целей и ценностей на ближайшие 2,3,5,10,20 лет, выстроить реальный план реализации всех целей, обнаружить все ресурсы и приступить к реализации плана.

6. Осознать или выработать своё предназначение, призвание и миссию на этой земле - своё Мета-Видение. 
1. По стилю:

\section{Виды коучинга}

Фристайл коучинг - это свободный стиль коучинга, когда клиент формулирует запрос на одну сессию за несколько дней до или прямо перед сессией. Многие клиенты, уже знакомые с коучем или коучингом на практике пользуются фристайл коучингом, так как эта форма даёт больше гибкости, и коуч и клиент еженедельно фокусируются на самых актуальных задачах клиента.

Процессный коучинг - это стиль коучинга, в основе которой лежит разработанная коучем (иногда совместно с клиентом) программа развития. Эта форма удобна для клиентов пока ещё слабо знакомых с коучингом, так как помогает клиенту ещё перед заключением контракта на коучинг представить целостно картину процесса и результатов коучинга. Примером программы, в основе которой лежит процессный коучинг, являются программы: «Новые возможности», «7 секретов мотивации» и «Пробуждение Духа».

2. По уровням изменений:

Коучинг можно представить на трёх уровнях изменений: поведенческий, развития и трансформационный.

Поведенческий коучинг - коучинг, нацеленный в первую очередь на изменения на уровне поведения. Это достигается за счёт выработки навыков, способностей, привычек, усвоения и тренировки новых стратегий поведения. (Примеры подобных навыков: проведение совещаний, делегирование, презентация, холодные звонки, работа с возражениями, создание раппорта, выяснение потребностей, активное слушание, постановка целей, создание ресурсного состояния и прочее).

Коучинг развития - коучинг, работающий с эволюционным развитием, развитием личности. На этом уровне осознаются базовые потребности (и их отличия от обязанностей и необходимостей), глубинные ценности (и их отличия от возможностей и навязанных стандартов), а также создаётся долгосрочная система целей - стратегия достижения желаемых результатов во всех областях жизни клиента. Здесь также планируются и разрабатываются способы приобретения новых свойств и качеств личности, для большей целостности.

Трансформационный уровень - затрагивает бытие человека, его предназначение и миссию на Земле. Изменения на этом уровне способны в корне и быстро изменить направление всей жизни человека. Здесь коучинг работает с Мета-Видением личности, а также с изменением ограничивающих убеждений и принятием кардинальных решений для полной самореализации человека посредством пути к Мета-Видению. Трансформационный коучинг - коучинг, работающий с революционными изменениями.

3. По количеству участников:

Индивидуальный коучинг - это работа коуча и клиента один на один с запросом, целью или над программой развития клиента.

Групповой коучинг - это коучинг или фасилитация группы (от 2 до 15 человек) по разработанной программе, заранее согласованному плану либо же во фристайл форме с текущими целями и задачами, которые возникли перед группой. (Примерами могут служить: мозговой штурм, SWOT-анализ, разработка генеральной стратегии, создание миссии и видения компании, повышение эффективности работы, создание программы качества, анализ рисков и создание 
плана реагирования, улучшение навыков продаж и качества обслуживания клиентов и прочее).

Частным примером группового коучинга может быть командный коучинг и семейный коучинг, когда на сессии присутствует от 2-х участников. Соответственно, командный коучинг работает с целями команды, семейный коучинг работает с целями семьи.

4. По форме:

По форме взаимодействия можно выделить четыре основных вида коучинга:

Очный - коуч-сессии проходят при личной встрече клиента с коучем.

Телефонный - коуч-сессии проходят по телефону.

Видеочат - коуч-сессии проходят с использованием Skype, iChat, etc.

Дистанционный - без личного контакта: e-mail, телеклассы, подкасты, тесты, задания, отчёты и прочее.

Смешанный - использует все или некоторые из вышеперечисленных форм.

\section{5. По содержанию:}

Содержанием коучинга всегда является запрос клиента, цели и результаты клиента, качество жизни и успех клиента.

Чем коучинг отличается от консультирования? От терапии? От спортивных тренировок? От общения с лучшим другом?

Консалтинг. Коучинг - это форма консультирования. Особенность заключается в том, что коуч остаётся (сопровождает) с клиентом, чтобы клиент действительно осуществил новые навыки, изменения и цели, чтобы убедиться, что они воплощаются в жизнь.

Терапия. Коучинг - не терапия. Коуч не работает с «проблемами», не обращается к прошлому и не выясняет причин человеческого поведения. Коуч оставляет это клиентам для их собственного познания, помогая им продвигаться вперёд, устанавливать свои личные и профессиональные цели, которые обеспечат им такую жизнь, о которой они мечтают.

Спорт. Коучинг включает в себя некоторые принципы тренировки перед спортивными соревнованиями, таких как, взаимодействие, продвижение к цели, стремление всё делать лучше. Но в отличие от тренировки, большая часть профессионального коучинга - не для победы над кем-то (по принципу «Выигрыш/Проигрыш»). Коуч усиливает навыки клиента, которые позволяет ему одерживать победы. Это - «Выигрыш/Выигрыш».

Лучший друг. Лучший друг - это замечательно. Но разве он профессионал в консультировании, которому можно довериться настолько, чтобы принимать его советы относительно важнейших аспектов жизни и/или бизнеса? Лучше всего, когда есть и лучший друг, и коуч ${ }^{17}$.

Переход к рыночным отношениям затрагивает одну из неконсервативных систем - систему образования. В педагогике появились термины, более понятны и привычны для экономической сферы (индикативное управление, индикативное планирование, педагогический аудит, коучинг). Адаптировать экономическую терминологию к педагогической практике очень непросто. Большинство людей не понимает, зачем это надо. Но с проникновением рыночных процессов в учебно-

\footnotetext{
17Электронный pecypc, режим доступа:http://coachingineducation.ru/kouching-kak-
} professionalno-pedagogicheskaya-kompetentnost-sovremennogo-uchitelya/ 
воспитательный процесс педагоги всё больше убеждаются в том, что экономические методы способны обогатить и усовершенствовать педагогические технологии ${ }^{18}$.

Концепции современного образования максимально соответствует коучинговый подход как эффективная, апробированная на практике система развивающего взаимодействия, а коучинговые навыки органично встраиваются в профиль компетенций современного учителя.

Коучинг - это искусство способствовать повышению результативности, обучению и развитию другого человека. Он опирается не на знание, опыт, мудрость или предвидение коуча, но в большей степени - на способность человека учиться самому и действовать творчески». (Дауни).

Овладевая технологией коучинга опираются на следующие философские и психологические основы: сократовские методы диалога, гуманистический подход в психотерапии (К. Роджерс, А. Маслоу), методику практикующих спортивных тренеров (Т. Голви), концепцию эмоционального интеллекта (Д. Гоулмен) и другие.

Педагогический коучинг - это специальная система, которая помогает, используя знания и опыт самого ученика, решить его определённые проблемы, задачи и поставленные цели, эта технология помогает, используя собственный потенциал, повысить производительность и эффективность учёбы, повысить самооценку. Педагогический коучинг - это целенаправленный процесс, который может проводиться как в форме индивидуальных занятий, так и в рамках организационного консультирования. Технология педагогического коучинга является базовой моделью тьюторства для сопровождения процесса индивидуального образования в школе, вузе, ссистемах дополнительного и непрерывного образования.

Педагогический коучинг призван:

1. Повысить эффективность педагогической деятельности.

2. Психологически грамотно сопровождать учеников по жизненному и образовательному пути.

3. Ставить перед собой и учениками реальные и релевантные цели.

4. Определить жизненные цели на краткосрочную и долгосрочную перспективу.

5. Развивать навыки управления личным временем.

6. Улучшить отношения в семье и с другими людьми.

7. Преодолеть стресс.

8. Повысить уверенность в себе.

9. Эффективно и быстро преодолеть неблагоприятные жизненные обстоятельства ${ }^{19}$.

На Западе парадигма коучинга, как особого стиля обучающего взаимодействия, развивалась на основе рефлексии передовых подходов в области наставничества и бизнес-консультирования. Эта технология помогала людям развиваться, осваивать новые навыки и достигать больших успехов, прежде всего, в бизнесе, управлении. В настоящее время идея коучинга стала реализовываться в педагогической практике.

\footnotetext{
${ }^{18}$ Ibidem.

19 Электронный ресурс, режим доступа: www.coachfederation.org
} 
Один из авторов внедрения коучинга в систему образования Н.М. Зырянов, рассматривает данное понятие в широком и в узком смысле этого слова.

В широком смысле коучинг - это «такая форма консультативной поддержки, которая помогает человеку достигать значимых для него целей в оптимальное время путём мобилизации внутреннего потенциала, развития необходимых способностей и формирования новых навыков». Согласно более узкому определению, коучинг это «процесс выявления целей человека и выработка оптимальных путей их достижения».

Педагогический коучинг (в переводе с англ. «coaching» (коучинг) означает наставление, тренерство) - продолжительное сотрудничество субъектов образовательного процесса, которое помогает достигать высоких результатов в процессе профессиональной подготовки.

Технология педагогического коучинга применяется в процессе организации профессионально-личностного развития будущих преподавателей высшей школы в процессе многоуровневой профессиональной подготовки. В настоящее время специальная подготовка преподавателей высшей школы осуществляется в рамках дополнительной квалификации «Преподавателей высшей школы», которая может быть реализована в магистратуре, аспирантуре (адъюнктуре), в учреждениях ДПО. В процессе многолетних исследований, пришли к выводу, что такой подход недостаточно эффективен, в процессе осуществления подготовки преподавателей высшей школы стали использовать технологию коучинга для вовлечения молодёжи, желающей получить квалификацию «Преподаватель высшей школы», в различные виды деятельности не только на этапе бакалавриата, но и начиная с довузовской подготовки. Выполняя функции коуча происходит процесс стимулирования профессионально-личностного развития будущих преподавателей, предоставляя «веер вариантов» построения индивидуальной образовательной траектории. Было выделено основные формы организации работы, которые реализовываются со студентами:

1. Работа в проблемных группах, участие в выполнении инновационных проектов в области образования, в Грантах и так далее.

2. Разработка и реализация социально-значимых проектов для молодёжи, представление их на конкурсах, форумах.

3. Разработка совместно с профессорско-преподавательским составом и помощь в апробации современных электронных продуктов учебного и воспитательного назначения.

4. Участие в конференциях, круглых столах, семинарах различного уровня.

5. Участие в инновационных форумах, посвящённых проблемам развития образования.

6. Участие в университетских инновационных технопарках. Бизнесинкубаторах (если они имеются в ВУЗе) и так далее 20.

Коучинг в образовании является темой мало изученной, даже за пределами Украины, поэтому развитие этого направления является чрезвычайно актуальным, учитывая цель образования по формированию нового поколения граждан.

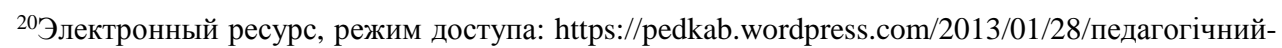
коучинг 
Цели коучинга в образовании:

1. Раскрытие внутреннего потенциала личности студента.

2. Развитие личности через делегирование ответственности.

3. Достижение высокого уровня ответственности и её осознание у всех участников коучинга.

Для достижения поставленных целей решаются следующие задачи:

1. Осуществляется диагностика и мониторинг образовательного процесса, позволяет учитывать и прогнозировать изменения, которые происходят в результате применения инновационных программ и технологий.

2. Создаются условия, направленные на эффективную организацию процесса поиска студентом путей достижения важных для него целей и выбора оптимального темпа продвижения.

3. Осваиваются инновационные методики и технологии.

4. Определяются ключевые моменты коучинга.

Коучинг решает проблему отсутствия мотивации. Основная особенность и отличие коучинга -содействие тому, чтобы человек сам научился, а не научить его. Без личной заинтересованности студента в обучении коучинг теряет всякий смысл, ведь личная мотивация студента является основой коучинга и залогом достижения поставленных целей. Важно, чтобы преподаватель-коуч мог профессионально рассказать о механизмах, парадоксах и влиянии мотивации на результат. Это стимулирует развитие и способствует достижению потенциальных возможностей студентов. Однако, стоит отметить, что коуч должен настраивать и мотивировать студентов не только на достижение цели и получения результатов, но и на приобретение опыта во время самого процесса обучения.

Феномен «коучинг» в высшей школе является принципиально новым направлением в педагогической науке и практике, в основу которого положено формулирование и максимально быстрое достижение цели путём мобилизации внутреннего потенциала, усвоение ведущих стратегий получения результата, развитие и совершенствование необходимых способностей и навыков. В контексте данной темы коучинг - это взаимоотношения между преподавателем и студентами, когда преподаватель эффективно организует процесс поиска студентами лучших ответов на вопросы, которые интересуют. Коуч помогает студентам развиваться, закреплять новые навыки и достигать высоких результатов в своей будущей профессии. Адаптация высшей школы к новым условиям в социальной, экономической, политической жизни может произойти только на основе положительного отношения к личности студента, а так же раскрытию его возможностей.

Парадигма коучинга как особого стиля учебного взаимодействия базируется на следующих позициях:

1. Люди способны изменяться только в тех случаях, когда сами захотят этого и готовы к этому.

2. Наши убеждения относительно собственных возможностей, напрямую связаны с нашими достижениями.

3. То, как мы определяем успех, оказывает прямое воздействие на наши достижения. 
4. Мы ограничиваем наш потенциал рамками наших убеждений (например, предполагая, что определённые вещи невозможны из-за внешних или ситуационных барьеров).

5. Люди учатся тогда, когда действительно вовлечены в процесс.

6. Мы можем учиться с помощью всего, что мы делаем, но обучение происходит только тогда, когда мы мыслим и строим планы на будущее.

7. Для того, чтобы помогать другим, нам необходимо непрерывно прогрессировать самим.

Принципы, которыми руководствуется коуч в процессе межличностного взаимодействия:

1. Принцип осознания и ответственности. Осознание предусматривает ответственность. Важно перейти от мотивации «избегания неудач» к мотивации «достижения успеха», изменения направления «от» на направление «до».

У коуча ответственность заключается в том, чтобы:

- Помочь студенту раскрыть то, чем он наделён, чем реально может распоряжаться для решения поставленных задач, для наиболее полной самореализации своего потенциала. Через осознание мы получаем доступ к нашим ресурсам. Способствую самосознанию студента, коуч помогает ему в большей степени понять самого себя.

- Помочь студенту выявить и понять то, что он действительно хочет достичь, сформулировать важные цели.

- Поощрять саморазвитие студента.

- Фасилитировать созданные студентом решения, помогать находить оптимальные пути, приносить удовольствие уже в ходе их поиска.

- $\quad$ Наделять студента ответственностью.

Иными словами, коуч несёт ответственность за процесс достижения результата, а студент - за результат и действия, связанные с его достижениями.

2. Принцип единства и взаимодействия предполагает, что положительные результаты в одной сфере деятельности приводят к достижениям в других. Осознание личностных проблем во взаимоотношениях влияет на другие виды деятельности.

3. Принцип гибкости. Формирование гибкости мышления, осознания стереотипов и алгоритмов своего поведения.Практика показывает, что почти каждый человек имеет большие трудности при попытке сделать что-то новое, изменить себя. Вместе с коучем разрабатывается поэтапное формирование новой стратегии как личностного, так и профессионального развития. Благодаря этому студенты верят в свои безграничные возможности и способности, необходимые им в дальнейшей профессиональной деятельности.

4. Принцип партнёрства предполагает коммуникативное сотрудничество, так называемые субъект-субъектные отношения. Коучинг направлен на формирование партнёрских отношений между коучем и студентами.

5. Принцип иерархичности развития. По выражению Альберта Эйнштейна наиболее важные проблемы, с которыми мы сталкиваемся не могут быть решены на том же уровне мышления, на котором мы были, когда их создавали. Ежедневно мы делаем выбор, принимаем важные решения. 
К сожалению, мы до сих пор нередко отталкиваемся от установок, стереотипов и опыта предыдущих побед и поражений, которые уже частично устарели. Коуч помогает преодолеть эти стереотипы и двигаться дальше.

Главная обязанность коуча заключается в том, чтобы найти лучшее в личности студента.

Главная обязанность студента заключается в том, чтобы взять на себя ответственность за решение поставленного задания и выполнить всё, о чём он договорился с коучем. Студент также несёт ответственность за свои результаты.

Мотивирующий импульс, побуждающий субъектов работать в системе «коучинг», - это потребность в изменениях.

Педагогическое общение в стиле «коучинг» поможет понять, почему студенты не смогли выполнить задание, поможет спланировать действия для нахождения оптимальных путей и научиться делать в будущем иначе.

Коуч способствует совершенствованию и максимально эффективному использованию личностных качеств студентов, о которых большинство или не догадывается, или догадывается, но не использует в качестве основы для дальнейшего движения вперёд. Он стимулирует студентов к более глубокому осознанию своих целей, ресурсов и ограничений, помогает определить направление развития личности вообще и профессионального развития в частности.

Работа с личностными ограничениями происходит в такой последовательности: «Кто я? - Чего я хочу? - Кем я хочу быть? - Каким я хочу быть? - Что мне мешает? - Как это преодолеть?». Результатом такой работы является способность студента самостоятельно выстроить позитивный ряд собственных убеждений: «Хочу! Могу! - Верю! - Делаю! - Есть результат!»

Таким образом, общую основу коучинга можно описать несколькими составляющими:

1. партнёрство;

2. раскрытие потенциала;

3. результат.

Коуч стимулирует творческий поиск решений и поддерживает стремление студентов достигать цели и осуществлять изменения в своей жизни. Иначе говоря, в процессе коучинга студенты находят свой, уникальный способ достижения цели. А коуч создаёт творческую атмосферу, особое пространство поиска альтернатив, атмосферу доверия, где студент чувствует внимание к его идеям и работает с большим энтузиазмом.

С другой стороны, коучинг возможен, когда личность сама формулирует и реализует самостоятельные проекты. То есть, студент обладает правом на принятие решений (или влияния на них) и несёт ответственность за результат.

Основные идеи образовательного коучинга:

1. Развитие человека как направление приоритетное в образовании.

2. Раскрытие потенциала человека для максимального его использования.

3. Помощь человеку развивать компетентность и устранить ограничения для достижения личностно значимых и устойчивых изменений в профессиональной и личной сферах жизни.

4. Помощь человеку учиться. Коуч привлекается для того, чтобы в сотрудничестве со студентом выработать и определить цели и задачи и разработать план действий по достижению этих целей. 
5. Коуч проявляет значительное влияние на своего подчинённого. Так, например, преподаватель может направить развитие профессиональных способностей студента и, в нём, по нашему мнению, должны отражаться все качества для достижения общей цели: воспитание и высококультурного человека, и профессионала своего дела.

Стержневая концепция коучинга: при формировании личности нельзя применять насилие, благими целями оно не обосновывалось бы. Благо человека - превыше всего.

Учитывая это, можно отметить, что основной идеей образовательного коучинга также является благополучие педагога, которое достигается плодотворным взаимодействием коуча и студента по достижение взаимноопределённых целей, однако, принятие решения осуществляется всегда преподавателем. Образовательный коучинг ориентирован на будущее и сфокусирован на решении конкретных деловых вопросов.

Коучинг является эффективным, если:

1. Студент понимает, что существует разница между тем, кто он есть, и тем, кем хотел бы быть.

2. Студент готов думать новым, непривычным для него способом.

3. Студент готов выслушивать и воспринимать критику в свой адрес.

4. Студент готов к осуществлению необходимых изменений и действует соответственно.

5. Студент соглашается с тем, что за результат несёт ответственность только он сам, а не коуч-преподаватель.

Одной из главных задач любого обучения является не только научить чему-то, но, прежде всего, научить учиться: получать, находить, искать необходимые знания. Именно коучинг запускает механизмы через личностную мотивацию студентов самостоятельно получать знания.

Коучинг - это своего рода партнёрство, и для того, чтобы взаимодействие коуча и студентов было продуктивным, необходимо соответствие и доверие партнёров. Личностный контакт и доверие между коучем и студентами является обязательным условием. У коуча существует особое понимание, связанное с тем, для чего и куда он ведёт за собой студентов, и как этот путь связан с их профессиональным развитием.

Основной критерий результативности коучинга -появление у студента в процессе обучения тех результатов, которые являются важными именно для него. Коуч фокусируется на личности студента, который хочет быть особенным, а не на том, чего хочет сам коуч.

Итак, педагогический коучинг предполагает:

1. Системное сопровождение студента, направленное на

эффективное достижение важных для него целей в конкретные сроки, в результате чего у субъекта формируется гибкость и адаптивность к изменениям, способность быстро и эффективно реагировать в критических ситуациях.

2. Партнёрское коммуникативное сотрудничество, помогает

добиваться значительных результатов в различных сферах

жизнедеятельности.

3. Непрерывный процесс развития, совершенствования, раскрытия потенциала личности для достижения максимального результата. 
4. Систему взаимодействия с коучем, с самим собой, с окружающим миром.

5. Технологию, позволяющую переместиться из зоны проблемы в зону эффективного решения.

6. Средство содействия, помощи личности в поиске её собственных решений в любой сложной для неё ситуации.

7. Модель взаимодействия субъектов, благодаря которой коуч-преподаватель повышает уровень мотивации и ответственности, как у себя, так и у студентов: «учится сам и учит других».

8. Особое поддерживающее отношение к студенту, согласно которому он сам достигает своей цели, сам решает проблемы, реализуя свои способности и возможности.

9. Вид индивидуальной поддержки личности ставит своей задачей профессиональный и личностный рост, повышение персональной эффективности.

10. Способ составления преподавательского коучинга состоит из следующих шагов:

- Установление партнёрских взаимоотношений между преподавателем и студентами.

- $\quad$ Совместное определение задач для достижения конкретной цели.

- Исследование текущей ситуации (проблемы).

- Определение внутренних и внешних препятствий на пути к результату.

- Выработка и анализ возможностей для преодоления трудностей в решении проблемы.

- В Выбор конкретного варианта действий и составление плана действий.

- Договорённость о том, что конкретно должно быть сделано и в какие сроки.

Следующее: коучинг-занятие всегда начинается с обзора - что сделано, что удалось и что можно было сделать лучше. В ходе реализации этих пунктов у студентов формируются убеждения:

- Я живу и действую «здесь и сейчас». - Я имею чёткое представление о своём будущем. - Я являюсь зрелой, самомотивирующейся личностью. - Я это возможность. - Я являюсь частью решения. - Группа - это я. - Я всё могу. Я - это средство оперативного решения различных задач. Я и люди, которые меня окружаю т- это высшая ценность. - Я знаю, как достичь поставленной цели. - Я знаю, что мне делать, и я это сделаю. - Я получаю удовольствие от деятельности. - Я реально оцениваю свои возможности и модели поведения. - Я определяю приоритеты и формулирую цели. - В группе все являются партнёрами. - Принятие решений должно быть коллективным.

Применение идей коучинга на практике означает постепенный переход от традиционных аудиторных занятий в тренинговой, индивидуальной, проектной, экстернатной и дистанционной форм работы.

Начало занятия - это определение цели занятия самим студентом. Любое занятие, даже занятия инициировано самим коучем, должно начинаться с того, что студент должен определить цели занятия. Студент должен чётко осознавать, что именно он хочет получить от каждого занятия, и какого результата он хочет достичь. Для этого преподаватель задаёт ряд вопросов:

1. Чего ты ждёшь от этого занятия?

2. У нас есть полчаса: что бы ты хотел успеть сделать за это время? 
3. Что бы было для тебя самым полезным на этом занятии?

4. Какая главная цель занятия?

5. Каких промежуточных целей нужно достичь в процессе достижения главной цели?

Промежуточные рабочие цели определяют уровень выполнения задания, достигнув которого, студент будет считать, что имеет все шансы достичь конечной цели. Самое важное для студента - взять на себя ответственность за достижение промежуточных рабочих целей. Такие цели, в отличие от конечных, поддаются контролю. Гораздо важнее для студента взять на себя ответственность за достижение промежуточных рабочих целей, чем конечных. Каждая конечная цель должна подкрепляться рядом промежуточных рабочих целей, достижение которых и является залогом достижения высшей, удалённой во времени и не всегда полностью зависимой от действий студента цели. Несмотря на то, что часто, как промежуточные рабочие, так и конечные цели, требуют доработки, корректировки и даже смены, постановка этих целей является важным этапом обучения.

Фасилитация - это организация в группе процесса коллективного решения проблем, соответственно управляет этим процессом - фасилитатор (ведущий, председательствующий).

Другим вариантом использования коучинга в образовании является его применение в качестве средства фасилитации эмоциональных проявлений в процессе взаимодействия преподавателя и студентов, направленный на облегчение групповой коммуникации с целью формирования умений регулировать свои эмоции и влиять на эмоциональное состояние партнёров, управлять собственным эмоциональным состоянием и влиять на эмоциональное состояние партнёров по работе.

Коучинг как эффективную психологическую практику целесообразно включать в систему научно-образовательных проектов в университетском образовании. Методы и приёмы коучинга могут гармонично вписаться в практику профессионально-личностного сопровождения студентов, как надёжный инструмент, позволяющий эффективно достигать целей не только в образовательном пространстве, но и собственно в профессиональном становлении будущих специалистов.

\section{Методы коучинга}

1. Метод конкретных ситуаций. Он основан на утверждении, что путь к совершенствованию собственных знаний возможно проложить только через рассмотрение, изучение и обсуждение конкретных проблемных ситуаций.

2. Метод эмоционального стимулирования. В основе этого метода обучения лежит принцип формирования познавательного интереса путём создания положительных эмоций к предложенному виду деятельности, повышения заинтересованности и мотивации к учебному процессу.

3. Метод создания ситуации познавательной дискуссии является действенным методом активизации обучения, ведь в дискуссии рождается истина, а поиск истины всегда вызывает усиленную заинтересованность темой.

4. «Мозаика»- метод распределения обязанностей в студенческой группе, когда распределение осуществляют сами студенты. Такой вид деятельности заставляет студентов самостоятельно, без помощи преподавателя-коуча распределять обязанности в группе и нести за данное деление ответственность. 
5. Метод проектов является методом, который выводит деятельность студентов на новый учебно-научный уровень. На этом уровне каждый из студентов осуществляет большой объём самостоятельной работы и обучается самоконтролю, что способствует самообразованию студентов. А научить студентов самостоятельно получать и применять знания на практике есть едва ли не главной и самой сложной целью современного образования.

Итак, основными функциями преподавателя-коуча являются:

1. Мотивационная - создание положительной мотивации к

профессионально-педагогической деятельности, формирование интереса к педагогической деятельности, позитивной установки на инновационную деятельность.

2. Воспитательная - формирование профессионально-педагогической направленности основанной на гуманистической профессиональной позиции.

3. Информационная - информирование о возможностях среды, о видах профессионально-педагогической деятельности, в которых можно участвовать.

4. Развивающая - способствовать развитию общекультурных и профессиональных компетенций, профессионально-значимых личностных качеств.

5. Организационная - вовлечение студентов в различные виды учебной, воспитательной, научно-исследовательской, инновационной деятельности.

6. Интегрирующе-дифференциальная функция - реализация которой позволяет организовывать эффективное взаимодействие студентов, направленное на раскрытие потенциала каждого студента в процессе выполнения совместных заданий.

7. Координирующая - формирование различных сценариев

профессионально-личностного развития будущих преподавателей в соответствии с их интересами и склонностями, а так же возможностями информационной профессионально-релевантной инновационной образовательной среды.

8. Фасилитационная - создание условий для более комфортного для будущих преподавателей освоения различных видов профессионально-педагогической деятельности; оказание помощи в процессе преодоления «барьеров» профессионально-личностного развития - неуверенности в своих силах, страх публичных выступлений и другие ${ }^{21}$.

Сегодня очевидно, что в «в новом стандарте учитель из транслятора знаний превращается в человека-навигатора, организатора учебной деятельности детей». Сейчас является актуальным передача технологий и знаний в сферу образования, и основной акцент делается на том, что должна меняться роль преподавателя: он становится человеком, в первую очередь, поддерживающим, создающим атмосферу творческого потока, помогающим пройти все вышеуказанные стадии любого эффективного проекта.

Современный учитель должен быть хорошим коучем, чтобы на каждом из этапов помогать ребёнку планировать свои действия и распределять ресурсы. Один

21 Электронный ресурс, режим доступа:

http://coachingineducation.ru/kouching-kak-professionalno-pedagogicheskaya-kompetentnostsovremennogo-uchitelya/ 
из основных принципов коучинга гласит, что каждый человек изначально обладает всеми необходимыми ресурсами. Учитель должен владеть технологиями, которые помогают эти ресурсы активизировать и направить в необходимое русло.

В коучинге есть инструменты, которые позволяют осознать свою ценность и значимость в профессии. Поэтому первоначальным в коучинге есть то, чтобы научить педагогов пользоваться собственными ресурсами, искать точку приложения полученных ранее знаний. Внедрение некоторых технологий коучинга в педагогическую практику, применение их на раннем этапе работы с ребёнком позволит изначально растить поколение формата инновационного: люди, начиная со школы, будут приучаться жить в состоянии фокуса внимания, создания новых проектов, улучшения качества своей жизни и жизни окружающих. Наиболее эффективным для педагогов является поэтапное внедрение коучинга и коучингового подхода в образовательном процессе. Было определено 3 этапа внедрения данной технологии в педагогический и образовательный процессы.

На первом этапе происходит обучение коучингу тех работников образования (педагогов, психологов, администрации), которые уже интуитивно применяют такой подход в своей работе, которым близки принципы коучинга.

В ходе занятий-тренингов на высоком профессиональном уровне помогают каждому педагогу-управленцу:

1. Освоить базовые коучинговые навыки (создание доверительных отношений, глубинное слушание, умение задавать эффективные вопросы).

2. Овладеть основными техниками коучинга, направленными на поддержание и развитие способностей человека, использование возможностей обучения для саморазвития, помощь учащимся в овладении навыками учения и саморазвития.

3. Научиться ставить цели и выстраивать технологию их достижения.

4. Прорабатывать собственные цели с помощью направленного поиска решения.

5. Применять на практике современные методы творческой командной работы и разрабатывать детальный план внедрения коучингового подхода в деятельность школы.

Серии простых вопросов, короткие беседы и практические упражнения позволили педагогам не только оценить для себя эффективность применения коучинга, но и открыть свои собственные коучинговыеспособности и навыки коучинга, а также в ходе проведённых тренингов попробовать себя в роли коуча и клиента.

На втором этапе обученные педагоги начинают применять полученные знания в практической деятельности, нарабатывая опыт, вопросы, ответы, собственные модификации коучинговых техник, адаптированных к учебно-воспитательному процессу. Таким образом, вокруг этих педагогов формируется особое образовательное пространство, вовлекающее как учеников, так и других педагогов. На этом этапе особенно важна поддерживающая среда, которую призвана организовать и развивать методическая служба.

На третьем этапе осуществляется обучение новых педагогов и распространение успешного опыта на конференциях, вебинарах, «круглых столах», открытых уроках, в публикациях и на форумах. При этом обучение новых педагогов осуществляется под руководством методистов информационно-методического центра теми педагогами, которые уже освоили коучинг в течение двух первых этапов. Педагоги 
стажировочной площадки на основании своего собственного опыта в ходе стажировочных практик демонстрируют, что применение коучинга в воспитании и обучении позволяет раскрывать ученикам предмет изучения легко, ярко, глубоко, что использование эффективных вопросов коучинга в диалогах с учениками гарантированно улучшает контакт с ними, что методы коучинга в диалогах «учитель-ученик» можно использовать в качестве профилактики всевозможных конфликтов и дисциплинарных проблем, что методика коучинга сама по себе не просто воспитывает человека, но также гарантированно помогает ему раскрывать в своей душе уважение, понимание других, сопереживание, согласие и желание помогать людям, желание сотрудничать, объединяться.

В ходе обучения коучингу педагоги делают множество открытий и получают новые идеи к размышлению о себе, о своей профессии и новых коучингинструментах в работе педагога, о прогрессивной методике воспитания, а также - о подлинной миссии учителя в нашем мире.

Демократические преобразования в современном обществе ведут к переоценке ценностей и повышению требований к качеству образования. Современный учитель должен научиться ценить в школьнике не столько умение читать, считать и решать задачи, сколько положительное отношение к самому себе, уверенность в своих силах, открытость внешнему миру, самостоятельность, инициативность, любознательность, а также развитые воображение, произвольность, коммуникативные способности, самооценку, а всё это в полной мере вбирает в себя методика коучинга ${ }^{22}$.

Таким образом, педагогический коучинг является феноменом образовательного процесса, построенный на мотивирующем взаимодействии, в котором преподаватель создаёт специальные условия, направленные на раскрытие личностного потенциала студента для достижения ним значительных для него целей в оптимальные сроки, в конкретной предметной области знаний. Базируется педагогический коучинг на развитии креативности студента и вдохновляющей деятельности преподавателя.

Недостатком коучинга в формальном образовании является только недостаток времени, который необходимо найти преподавателю для общения с каждым студентом. Однако, перспектива внедрения индивидуальной образовательной траектории даёт надежду на использование и таких новейших технологий как педагогический коучинг 23 .

В последнее десятилетие концепция эмоционального интеллекта как альтернативы традиционного интеллекта стала широко известной в психологической и управленческой науке. Многие сторонники данной концепции утверждают, что эмоциональный интеллект играет существенную роль в успешности управленческой деятельности. Например, некоторые авторы (D.Goleman, R.Cooper, A. Sawaf) считают, что коэффициент эмоционального

\footnotetext{
22 Электронный ресурс, режим доступа: www.coachfederation.org

23Электронный ресурс, режим доступа:

$\mathrm{http}$ //coachingineducation.ru/kouching-kak-professionalno-pedagogicheskaya-kompetentnostsovremennogo-uchitelya/
} 
интеллекта, он же EQ (emotionalquotient) имеет большую ценность для руководителя чем (intelligencequotient).

Специфика подготовки менеджера продиктована содержательными и результативными компонентами профессии: менеджер-организатор конкретных видов работ в рамках отдельных подразделений или программно-целевых групп, руководитель предприятия в целом или его подразделений (управлений, отделений, отделов), руководитель по отношению к подчинённым, администратор любого уровня, организующий работу на основе современных методов.

В настоящее время в сфере управления используют различные способы и подходы к работе с персоналом. И одним из самых новых, объединяющих в себе различные методики и техники, дающим новые возможности, признан коучинг как важный инструмент влияния на результаты деятельности отдельных людей и организации в целом. Современное управление в стиле коучинг - это взгляд на сотрудников как на огромный дополнительный ресурс предприятия, где каждый сотрудник является уникальной творческой личностью, способной самостоятельно решать многие задачи, проявлять инициативу, делать выбор, брать на себя ответственность и принимать решения.

Ниже приведены основные из приоритетов внедрения коучинга в управленческой деятельности:

1. Профессиональная подготовка менеджера рассматривается как процесс формирования личности в процессе обучения будущего специалиста, результатом которого выступает его готовность к профессиональной деятельности на основе устойчивой управленческой позиции и личностных качеств, базовых компетенций, саморегуляции личности и профессионального поведения менеджера. Специфика подготовки менеджера определена в первую очередь насыщенностью и значимостью человеческих отношений в управлении, где эмоциональная компетентность занимает центральную позицию и обусловливает эмоциональную сдержанность, эмоциональную уравновешенность, эмпатию, экспрессивную сензитивность, действенность, (способность увлечь за собой людей, активизировать их деятельность, найти наилучшие средства эмоционально-волевых воздействий и правильно выбрать момент их применения), комуникативные управленческие способности, включающие способности управлять собственными эмоциями в общении и так далее.

2. Применительно к подготовке менеджера, а также формированию его эмоциональной компетентности коучинг - это способ фасилитации личностного развития студентов с целью формирования умений управления собственным эмоциональным состоянием и навыков влияния на эмоциональное состояние партнёров по взаимодействию.

3. Подготовка специалистов в области менеджмента и управления относится к человековедческим профессиям, которые активно востребуют коммуникативный компонент труда и эмоциональные ресурсы субъекта в труде. Активно развиваемый компетентностный подход в подготовке менеджера характеризуется прагматическими целями (формирование компетенций), направлен на актуальные потребности современного профессионального образования, выраженные в современных тенденциях подготовки управленческих кадров и достижение измеряемых результатов готовности менеджера взаимодействовать и воздействовать на других людей, а также управлять собственным развитием. 
4. Базисом готовности менеджера к профессиональной деятельности выступает компетентность как способность и опыт реализации субъекта в профессии. Эмоциональная компетентность представляет собой совокупность способностей, знаний, умений и навыков в эмоциональной сфере, позволяющую управлять собственными эмоциями и создавать благоприятную эмоциональную атмосферу в процессе коммуникации.

5. Педагогическая модель формирования эмоциональной компетентности будущего менеджера на основе коучинга базируется на определении цели (достижении целей студента в области повышения уровня эмоциональной компетентности оптимальными путями и в оптимальные сроки), задачах (формировании самопознания, социального познания, саморегуляции, управлении эмоциями других), содержании (самосознании, социальном понимании, регуляции и управлении собой, управлении отношениями). К технологиям коучинга отнесены следующие шаги: самоидентификация студента в проблеме, преодоление узких рамок проблемы и обозначение дополнительных перспектив, вход в различные перспективы, фасилитация выбора, планирование ситуации, ответственное восприятие плана, действия по воплощению плана. Результат, проектируемый в модели - сформированность эмоциональной компетентности по критериям самопонимания и взаимопонимания, саморегуляции и взаиморегуляции.

6. Авторская технология реализации модели формирования эмоциональной компетентности будущего менеджера в процессе коучинга включает вводную сессию коучинга (знакомство, определение стратегии и перспектив развития), демонстрацию навыков, анализ и поиск новых ресурсов (коуч-сессии - личные и групповые), завершающую сессию коучинга (план действий, распределение ответственности, система мотивационных мер, необходимые ресурсы и так далее).

7. Рекомендации по внедрению коучинга в целях формирования эмоциональной компетенции будущего менеджера описывают технологию внедрения авторской модели коучинга и требования к методическому обеспечению данного процесса (разработка и апробация программы, создание научнометодической основы, контроль процесса подготовки менеджера и экспертиза результатов готовности специалиста).

Профессиональная подготовка менеджера рассматривается как процесс формирования личности и деятельности специалиста, результатом которого выступает его готовность к профессиональной деятельности на основе устойчивой управленческой позиции и личностных качеств, базовых компетенций, саморегуляции личности и профессионального поведения менеджера. Центральным понятием такой подготовки выступает компетентность специалиста как готовность и опыт реализации субъекта в профессии.

Была определена специфика подготовки менеджера с помощью коучинга: вопервых, это насыщенность и значимость человеческих отношений в управлении, вовторых, эмоциональная компетентность занимает центральную позицию и обусловливает эмоциональную сдержанность, эмоциональную уравновешенность, эмпатию, экспрессивную сензитивность, действенность, в-третьих, в деятельности менеджера важны такие качества, как способность увлечь за собой людей, активизировать их деятельность, найти наилучшие средства эмоционально-волевых воздействий и правильно выбирать момент их применения, в-четвёртых, базисом успешности менеджера являются коммуникативные и управленческие способности, 
включающие способности управлять собственными эмоциями в общении и тому подобное.

С опорой на выявленную специфику профессиональной подготовки управленческих кадров были определены место и роль эмоциональной компетентности в данном процессе. Она представляет собой совокупность способностей, знаний, умений и навыков в эмоциональной сфере, позволяющую управлять собственными эмоциями и создавать благоприятную эмоциональную атмосферу в процессе коммуникации.

Педагогическая модель формирования эмоциональной компетентности будущего менеджера реконструирует основные целевые компоненты работы самои взаимопонимание, само- и «узаиморегуляция»), определяет технологии их достижения и критерии эффективности подготовки будущих менеджеров ${ }^{24}$.

Преимуществом коучинга является доказательство того, что цели, которые человек ставит перед собой сам, достижимые. ${ }^{25}$ Цели, которые ставит руководитель своему подчинённому, могут входить в конфликт с внутренними ценностями и стремлениями, что приводит к появлению внутреннего подсознательного нежелания работника действовать. Это, в свою очередь, снижает эффективность работы. В процессе коучинга работник ставит цели и выбирает пути их достижения сам $^{26}$.

Недостатков в коучинге по определению быть не может. Он ориентирован на человека, на его мир, ценности и цели. Поэтому с точки зрения достижения данным конкретным человеком успеха, коучинг идеальный инструмент. Если же рассматривать его в системе координат других целей, то проблемы могут возникнуть. В процессе труда может выясниться, что цели и ценности работника не совпадают с целями и ценностями учреждения. Поэтому механизм коучинга может быть проведён руководстом с целью адаптировать сотрудника и помочь ему быть эффективным на своём рабочем месте при достижении учреждением своих стратегических и тактических целей ${ }^{27}$.

Коучинг является действенной составляющей концепции управления человеческими ресурсами, поскольку применяется в планировании, отборе, адаптации, мотивации, обучении, развитии, аттестации и оценке персонала. Это система, которая позволяет увидеть, почувствовать новые подходы и возможности, позволяет раскрыть потенциал и «навести порядок» во многих сферах общественной жизни. Она учит человека думать по-новому. Технология коучинга является инновационным механизмом, позволяющим личности развиваться и достигать определённых результатов в жизни.

24 Д.В. Ненашев, Название работы: диссертация «Коучинг как эффективная технология формирования эмочиональной компетентности будущих менеджеров», канд. пед. наук. Моск. гос. университет технолог. и управ., Москва, 2009, http://www.dissercat.com/content/kouching-kak-effektivnaya-tekhnologiya-formirovaniyaemotsionalnoi-kompetentnosti-budushchik

${ }^{25}$ А.В. Самсонова, [электронный ресурс] Режим доступа: http://www.elenasamsonova.com/_business / coaching

${ }^{26}$ Вільнаенциклопедія [электронный ресурс] Режим доступу: http://ru.wikipedia.org/wiki

27 А.В. Самсонова, [электронный ресурс] Режим доступа: http://www.elenasamsonova.com/_ business / coaching 
Данный метод управления персоналом является весьма положительным и эффективным. Однако не все работники могут приспособиться к этому и быть успешными в своей сфере. Поэтому необходимо совершенствовать механизм управления персоналом, применяя метод коучинга.

Что касается перспектив, то коучинг будет развиваться и находить своё место. Bсё это будет происходить примерно так же как с PR и маркетингом. В начале это были непонятные иностранные слова. Затем появились первые тренинги и специалисты. Затем процесс формализовался. Теперь существуют свои школы, свои гуру и признанные техники и технологии работы. Коучинг ждёт нечто подобное.

Итак, коучинг - это будущее эффективного и прогрессивного управления персоналом, который вскоре займёт ведущую позицию в стратегиях различных учреждений многих стран мира ${ }^{28}$.

В условиях инновационного вектора развития человечества актуальным становится поиск новых способов управления человеческим капиталом. В связи с этим и возрастает роль коучинга как главного инструмента образовательного процесса, как бизнес-инструмента для менеджеров всех уровней в структуре компании. Кардинальные изменения деятельности передовых предприятий показывают, что персоналу требуется, чтобы менеджеры улучшали свои навыки работы с подчинёнными в стиле коучинга и вели сотрудников по пути профессионального роста. Коучинг применяется в любом бизнесе - от производства до розничной торговли, от сферы обслуживания до финансовых услуг. Европа, и в особенности Великобритания, Скандинавские страны и Нидерланды, применяют коучинг как основной стиль менеджмента. Коучинг необходим в первую очередь тем, кто стремится к своему развитию, наиболее полному раскрытию своего потенциала и достижению максимальной эффективности своего бизнеса, своей жизни.

Несмотря на проблемы развития коучинга, спрос на данный вид услуг постепенно увеличивается, а значит, данный инструмент может быть использован в качестве эффективного способа решения проблем в бизнесе, культурнополитической деятельности и даже в повседневной жизни человека (быту).Дальнейшие исследования в данном направлении являются перспективными. В частности, актуальны вопросы изучения основных методик, инструментов и теорий коучинга, а также государственного механизма регулирования коучинга в мире ${ }^{29}$.

\section{БИБЛИОГРАФИЯ:}

[1] Борова Т., Коучинг як механізм спрямованоїамоорганізації, Теорія та методика управління освітою 2010, № 3, с.1-11.

[2] Вільнаенциклопедія [Електронний ресурс] Режим доступу:

\footnotetext{
${ }^{28}$ Т. Борова, Коучинг як механізм спрямованоїсамоорганізації, Теорія та методика управління освітою 2010, № 3, с. 103.

${ }^{29} \mathrm{H}$. А. Слободянюк, Возникновение $u$ развитие школь коучинга: зарубежный $u$ отечественный onыm, Н. А. Слободянюк, Вісник Дніпропетровського університету. Сер., Економіка 2013, Т. 21, вип. 7(3), с. 205-206.
} 
http://ru.wikipedia.org/wiki

[3] Демоз, Л. Психоистория, Ллойд Демоз, Ростов-на-Дону, 2000, 510 с. Электронный ресурс, режим доступа: http://www.i.booksgid.com/web/online/4164

[4] Зборовська Н., Код української літератури : проект психоісторї̈новітньої української літератури, Н. Зборовська, К. Академвидав, 2006, 504 с.

[5] Ненашев Д.В., Название работы: диссертаиия «Коучинг как эффективная технология формирования эмочиональной компетентности будущих менеджеров», канд. пед. наук. Моск. гос. университет технолог. и управ., Москва, 2009, http://www.dissercat.com/content/kouching-kak-effektivnayatekhnologiya-formirovaniya-emotsionalnoi-kompetentnosti-budushchik

[6] Слободянюк Н. А.,Возникновение и развитие школь коучинга: зарубежный и отечественный опыт, Н. А. Слободянюк, Вісник Дніпропетровського університету. Сер., Економіка 2013, Т. 21, вип. 7(3), с. 199-206.

[7] Самсонова А.В., [Электронный ресурс] Режим доступа: http://www.elenasamsonova.com/_ business / coaching

[8] Режим доступу: http://nbuv.gov.ua/UJRN/vdumov_2013_21_7(3)_29

[9] Электронный ресурс, режим доступа: www.coachfederation.org

[10] Электронный ресурс, режим доступа:http://coachingineducation.ru/kouchingkak-professionalno-pedagogicheskaya-kompetentnost-sovremennogo-uchitelya/

[11] Электронный ресурс, режим доступа:http://www.lifecoaching.in.ua/coaching/

[12] Электронный ресурс, режим доступа: https://pedkab.wordpress.com/2013/01/28/педагогічний-коучинг

[13] Электронный ресурс, режим доступа: http://www.rusnauka.com/21_NNP_2010/Pedagogica/70725.doc.htm

[14] Электронный ресурс /Режим доступа: https://ru.wikipedia.org/wiki/Коучинг

\section{PSYCHOHISTORICAL DISCOURSE}

\section{UKRAINIAN HISTORY XX-XXI ARTICLES}

There are a few periods of Ukrainian history in the article which are considered through the prism of psychohistory. Particularly it concerns impetuous $20^{\text {th }}$ century, when the issues of totalitarianism made scientists worry. The research of L. de Mause is taken as the core of the research of such problem, which is the cult for a psycho-historian and as an example of an integral model there is a literary psycho-historical model of $\mathrm{N}$. Zborovskaya.

There exists an ultimate and linear connection between upbringing and childhood peculiarities and a style of their psychopolicy according to L. de Mause. In his work he also puts a question "whether democracy wins?", the researcher draws an analogy between the process of restructuring and the Duma's experiments of 1905-1907s years.

In the cultural space of the $20^{\text {th }}$ century, which $\mathrm{N}$. Zborovskaya analyzed, the researcher outlined postmodern as a key cultural phenomenon which was studied from psychoanalytical prospective.

Ukraine came into the 21 st century with a wide range of acute crises and revolutions which endangered all prospects of its vital activity. Recognition of this necessity of society's psychological regeneration is carried out by our government through the attraction of social psychologists first of all to different educational establishments. Mastering such strategies which increase personality effectiveness of every person and strengthen his mental health are the main features of the $21^{\text {st }}$ century. Authors consider coaching as a following constructive example of the similar strategy. Coaching is an effective component of human 
resources management process as it is applied in planning, selection, adaptation, motivation, training, development, certification and assessment of staff. This system, which allows to see, feel a new approach and opportunities, enables to open potential and "to put yourself in order" in many spheres of social life. It stimulates an individual to increase personal efficiency not through exhaustion of psycho-emotional areas, but through a set of special tools directed at the sphere of self-discovery.

Keywords: Psychohistorical discourse, L. de Mause, Ukraine

\section{PSYCHOHISTORYCZNY DYSKURS UKRAIŃSKIEJ HISTORII XX-XXI}

WIEKU

Celem artykułu jest charakterystyka procesów psychohistorycznych, które miały miejsce w historii narodu ukraińskiego w XX-XXI wieku. Opracowanie jest podzielone na trzy części. Istnieje kilka okresów w kontekście psychohistorii, które są brane są pod uwagę w artykule. Szczególnie dotyczy to porywczego XX wieku, kiedy kwestie totalitaryzmu zdominowały dyskusje społeczne. Badania L. de Mäuse są traktowane jako rdzeń badawczy tego problemu. Istnieje ostateczny i liniowy związek między wychowaniem i osobowością z dzieciństwa według L. de Mäuse. W swojej pracy stawia też pytanie, "czy demokracja wygrywa?", Badacz zwraca uwagę na analogię między procesem restrukturyzacji i eksperymentów przez Dumę w latach 1905-1907.W przestrzeni kulturowej XX wiekuN. Zborovskaya przedstawia postmodernistyczną koncepcję jako kluczowe zjawisko kulturowe, które badano z perspektywy psychoanalitycznej.Ukraina w XXI wieku wyszła z wielu ostrych kryzysów i rewolucji, w czasie których zagrożone były wszystkie perspektywy życiowej aktywności. Rząd ukraiński wskazał na konieczność regeneracji psychicznej społeczeństwa prowadzonągłównie przez psychologów społecznych w różnych placówkach edukacyjnych. Zdaniem autorów artykułu opanowanie strategii, które zwiększają efektywność każdego człowieka i wzmacniająa jego zdrowie psychiczne to główne cechy XXI wieku. Autorki artykułuoceniają coaching jako konstruktywny element rozwoju osobowościowego. Ich zdaniem coaching jest także skutecznym składnikiem procesu zarządzania zasobami ludzkimi, ponieważ jest stosowany w planowaniu, rekrutacji, motywacji oraz podczas oceny pracowników. To system, który pozwala otworzyć potencjał i pobudza osobę w celu zwiększenia wydajności poprzez osobisty rozwój.

Słowa kluczowe: Psychohistoryczny dyskurs, L. de Mause, Ukraina.

DOI:10.7862/rz.2015.hss.48

Przesłano do redakcji: październik 2015

Przyjęto do druku: grudzień 2015 